\title{
Habitat use and site fidelity of neonate and juvenile green sawfish Pristis zijsron in a nursery area in Western Australia
}

\author{
David L. Morgan ${ }^{1, *}$, Brendan C. Ebner ${ }^{1,2,3}$, Mark G. Allen ${ }^{1}$, Adrian C. Gleiss ${ }^{1}$, \\ Stephen J. Beatty ${ }^{1}$, Jeff M. Whitty ${ }^{1}$ \\ ${ }^{1}$ Freshwater Fish Group \& Fish Health Unit, Centre for Fish \& Fisheries Research, School of Veterinary and Life Sciences, \\ Murdoch University, Murdoch, Western Australia 6150, Australia \\ ${ }^{2}$ TropWATER, James Cook University, 47 Maunds Road, Atherton, Queensland 4883, Australia \\ ${ }^{3}$ CSIRO Land and Water, Atherton, Queensland 4883, Australia
}

\begin{abstract}
The largest of the sawfishes is the Critically Endangered green sawfish Pristis zijsron, a species believed to have undergone a major decline (38\%) in extent of occurrence. Conservation efforts are hampered by the lack of information on the habitat requirements of this species. We used passive acoustic telemetry to document the movement patterns of 37 juvenile $P$. zijsron $(<3000 \mathrm{~mm}$ total length) in a recently discovered nursery area in a remote estuary and adjacent mangrove creeks in the Pilbara region of Western Australia. All age classes had a high site fidelity near the mouth of the Ashburton River $(<700 \mathrm{~m}$ upstream) or in the adjacent tidal mangrove creeks. Neonates stayed close to the river mouth for several months, with movement increasing with growth. For larger individuals, movement between the river mouth or creeks and nearshore coastal habitats was largely tidally driven, with nearshore coastal habitats used during low tide and protected tidal waters (mangrove creeks) used during high tide. Emigration from the river estuary appeared to be influenced by increases in freshwater discharge and high turbidity brought on by cyclonic rainfall events. The high relative abundance and site fidelity of multiple age classes of $P$. zijsron over multiple years confirms that the study area provides important nursery habitats for the species. Additionally, the localised movements of juveniles suggest that this population may be sensitive to disturbances within these habitats. Given the significance of this region for $P$. zijsron, it is imperative to focus conservation efforts here to ensure that the population remains in a relatively healthy condition.
\end{abstract}

KEY WORDS: Pristidae $\cdot$ IUCN $\cdot$ Elasmobranchs $\cdot$ Telemetry $\cdot$ Pilbara

\section{INTRODUCTION}

Of the chondrichthyan fishes, those that are largebodied and occur in shallow waters are at the greatest risk of extinction (Dulvy et al. 2014). The most threatened family of chondrichthyans is the Pristidae (sawfishes), a unique family of large-bodied rays (Last \& Stevens 2009, Dulvy et al. 2014, 2016). Globally, all pristids have declined in their extent of occurrence (e.g. Simpfendorfer 2000, Fernandez-Carvalho et al.

${ }^{*}$ Corresponding author: d.morgan@murdoch.edu.au
2014, Leeney \& Poncelet 2015, Moore 2015, Dulvy et al. 2016), and although the susceptibility of the rostrum to entanglement in fishing nets is a major reason that the extent of occurrence of all 5 species has declined (each is currently listed as either Critically Endangered or Endangered by the IUCN), other threatening processes have also contributed to their imperilment. These processes include loss of nursery habitats (Kyne et al. 2013), barriers to migration and reduction in habitat quality as a function of river reg-

(C) The authors 2017. Open Access under Creative Commons by Attribution Licence. Use, distribution and reproduction are unrestricted. Authors and original publication must be credited. 
ulation (Thorburn et al. 2007), targeted fisheries (Thorson 1982) including for cultural or medicinal purposes, and taking of rostra as curios (McDavitt 1996, Seitz \& Poulakis 2006, Morgan et al. 2011, 2016, Whitty et al. 2014).

The importance of identifying nursery habitats and examining site fidelity for endangered species is crucial for conservation efforts. Pristid nurseries occur in relatively shallow coastal waters, and in the case of the freshwater sawfish Pristis pristis, extend into both estuarine and riverine environments (Simpfendorfer 2000, Seitz \& Poulakis 2002, Peverell 2005, Thorburn et al. 2007, 2008, Whitty et al. 2009, Morgan et al. 2011, 2015). These habitats are often subjected to human development along with high levels of commercial and recreational fishing activity (Nagelkerken et al. 2015, Sheaves et al. 2015). Consequently, the effective conservation of pristids at the species and population levels is likely to depend in part on the identification and protection of nursery habitats from these activities (e.g. Whitty et al. 2009, Simpfendorfer et al. 2010, Morgan et al. 2015). An understanding of the ontogenetic habitat partitioning and migration patterns within nurseries is also important for sustainably managing pristid populations along developed and developing coastlines.

Empirical studies on the ecology, migration patterns, and nursery habitat use are lacking for most pristid species, although telemetry-based applications are beginning to fill these knowledge gaps for some. Age-specific depth occupation and migration from nursery habitat is exhibited by $P$. pristis in northwestern Australia (Whitty et al. 2009, Whitty 2011). For example, young-of-the-year $P$. pristis remain in very shallow waters (e.g. generally $<0.5 \mathrm{~m}$ ), whereas fish into their second year of life occupy the same habitats but at greater depths, presumably as a response to predator avoidance, for feeding and/or to limit stranding in macrotidal environments (Whitty et al. 2009). Similarly, juvenile smalltooth sawfish $P$. pectinata have an affinity for shallow-water mangrove habitats and occupy increasingly larger space as they grow (Simpfendorfer et al. 2010, Poulakis et al. 2013, Hollensead et al. 2016). However, apart from P. pristis and P. pectinata, there is little information on the use of habitats by juvenile sawfish and it is hypothesised that other members of this morphologically similar family are likely to exhibit similar habitat use patterns (Whitty et al. 2009, Simpfendorfer et al. 2010).

One of the largest and least-studied pristids is the green sawfish $P$. zijsron. This species is believed to have undergone a major decline in the extent of occurrence (38\%) within its former Indo-West Pacific range (Moore 2015, Dulvy et al. 2016). The species is thought to have become extinct in most of eastern Australia and parts of southeast Asia and represents South Africa's first marine elasmobranch extinction (Everett et al. 2015, Dulvy et al. 2016). There are few reliable contemporary records of the species throughout its former range, and most recent records are from northern Australia, whose coastal waters perhaps offer a globally important refuge for 4 of the pristids (Peverell 2005, Morgan et al. 2011, 2015). Recently, a nursery for P. zijsron was identified in an estuary and its adjoining mangrove creeks in the eastern Indian Ocean (Pilbara) region of Western Australia (Morgan et al. 2015).

In the current study, passive acoustic telemetry was used to examine residency and habitat associations of juvenile $P$. zijsron to determine the relative importance of coastal waters, a river estuary, and mangrove creeks for juvenile $P$. zijsron as a first step to inform strategies for conserving this species in a region facing rapid industrial development.

\section{MATERIALS AND METHODS}

\section{Study areas, sampling methods, and tagging}

The Pilbara region is hot and arid, with mean maximum summer and winter air temperatures being 35.2 and $25.6^{\circ} \mathrm{C}$, respectively. The study commenced in 2011 in the Ashburton River and adjacent tidal mangrove creeks near the town of Onslow, Western Australia $\left(21.64^{\circ} \mathrm{S}, 115.11^{\circ} \mathrm{E}\right)$, which at the time had a human population of 667 . It is an extremely remote and isolated town, being $1380 \mathrm{~km}$ north of Perth, the capital of Western Australia. Rainfall is sporadic (mean annual rainfall is $275.8 \mathrm{~mm}$ ) and the Ashburton River flows periodically, usually after summer or autumn cyclonic events. Targeted sampling for sawfish occurred during April and October 2011, in short mangrove creeks north of the Ashburton River delta, Hooley Creek and Four Mile Creek (Fig. 1), and in the Ashburton River delta (see Morgan et al. 2015). Both of the tidal mangrove creeks are without freshwater tributaries; however, Hooley Creek occasionally receives freshwater input following large flooding of the Ashburton River floodplain.

Sampling consisted of setting gill nets (100 or $150 \mathrm{~mm}$ monofilament stretched mesh, of $60 \mathrm{~m}$ length) perpendicular to the bank in Four Mile Creek, Hooley Creek, and the Ashburton Estuary (see Morgan et al. 2015). When captured, green sawfish Pristis zijs- 




Fig. 1. Study areas (top panel; inset: Western Australia), Ashburton River (lower left panel), and Hooley Creek and Four Mile Creek (lower right panel), showing locations and identification numbers of VR2W and VR4-Global receivers in the acoustic array

ron were measured (stretched total length, TL), sexed, and the maturity status of males based on clasper morphology was noted. The majority of $P$. zijsron captured were fitted with a $69 \mathrm{kHz}$, coded V13 acoustic transmitter (Vemco). Tag attachment was consistent with that used by Whitty et al. (2009). Acoustic transmitters were attached to Rototags (Gallagher Supertags) and then fastened to the first dorsal fin of each sawfish. An additional Rototag was secured to the second dorsal fin of $>0+$ P. zijsron $(>12$ months of age), which acted as a reserve identification tag to help determine whether the acoustic tag was shed from recaptured individuals. Transmitters were tested before deployment using a VR2W acoustic receiver. Each transmitter was fitted with a temperature sensor, which had a temperature range of $0-40^{\circ} \mathrm{C}$, and a pressure sensor, which had a range of 0-50 m, although the majority of pressure sensors malfunctioned. Each tag randomly transmitted a signal at intervals of between 50 and $90 \mathrm{~s}$. The estimated battery life of each tag was $514 \mathrm{~d}$.

Prior to the tagging of sawfish with acoustic tags, 12 VR2W acoustic receivers attached to moorings were installed throughout the study area. Site selec- 
tion of the moorings adhered to conditions provided by the Department of Transport, Government of Western Australia, which precluded moorings being installed in navigational waters. The acoustic receivers in the array included: 2 units within Four Mile Creek, 2 outside the mouth of Four Mile Creek, 2 placed within Hooley Creek, 1 placed in the mouth and 1 outside the mouth of Hooley Creek, 3 within the Ashburton River, and 1 outside of the Ashburton River mouth (Fig. 1). Acoustic receivers were downloaded and cleaned of biofouling annually to semiannually during the study period. Additionally, during October 2011, a VR4-Global receiver (Vemco) was installed near the entrance of each of the creeks and in the Ashburton River mouth. Two of the VR4Global receivers ceased functioning in early 2012. The unit deployed at the mouth of Hooley Creek began malfunctioning during the week prior to 23 January 2012, the unit deployed at the mouth of the Ashburton River malfunctioned during the week prior to 12 March 2012, and the third ceased to operate in August 2012. For consistency, data from the VR4-Globals was only used to examine neonate movements in the Ashburton River, but they served as a valuable tool to receive data without the need to physically download the receivers (see Fig. 4).

\section{Data analysis}

A residency index (RI) was calculated for tagged sawfish, with the index calculated as the number of days a fish was detected divided by the number of days it was at liberty (i.e. the number of days between when the sawfish was tagged and when it was last detected). A sawfish was considered to be present in an area if it was detected more than once in a day. Single detections were excluded from analyses to reduce the risk of incorporating false-positive detections and only accounted for $0.06 \%$ of all detections. Mean residencies of sawfish within the different regions (tributary and coastal) and age classes (see end of this section) were compared to determine differences in spatial and temporal habitat use. This was performed by running arcsine-transformed RIs through an ANOVA. The number of contiguous days a sawfish was present and absent from the study area was also calculated.

The total distance individual $P$. zijsron moved between creeks was calculated by counting the number of movements between creeks and multiplying this by the distance between the respective creeks. This calculation should be considered to be very conser- vative as it measured the minimum distance between creeks and did not account for additional movement in coastal waters. The total distance was standardised by dividing by the number of days the fish was at liberty. A Pearson product-moment correlation was used to compare the inter-creek distance travelled with the TL of the fish. This test was repeated to determine the correlation between the various size classes and the percentages of those size classes that moved between creeks.

Diel shifts in acoustic detections of tagged animals may develop as a result of movement by the animal or disruption of acoustic transmissions by environmental factors like wind or waves. The effects of tides and wind on number of detections were assessed via Akaike's information criteria (AIC) comparisons of generalised additive mixed models (GAMM) performed in the $\mathrm{R}$ package mgcv using a Gaussian error structure (Wood 2006). This analysis was repeated for 2 habitat types (e.g. protected tributaries and unprotected coastal environments). Included fixed effects were tide height, wind speed, and wind direction (collected from the State Government's Bureau of Meteorology). Fish identification was included as a random effect in all models. The most parsimonious and best-fit model (lowest AIC value) for coastal and tributary systems was selected. Visual analyses of residuals and quantile-quantile plots were used to ensure that the validity of distributional assumptions of the GAMM were met.

The influence of tides on sawfish presence was further investigated through the use of a chi-squared goodness-of-fit test. In this test, tide heights were binned into $50 \mathrm{~cm}$ intervals and number of visits (e.g. 30 min periods when sawfish were present) from the various tributaries and the coastal habitats were pooled into respective bins. The number of observed visits at each tide height in each region was compared with the frequency of occurrence of each tide height during the study.

A chi-squared goodness-of-fit analysis was used to test the null hypothesis that the direction of sawfish movements to and from a tributary were not influenced by tidal flow, i.e. movements in and out of tributaries were equally likely with and against the direction of flow. In the analysis, the observed number of fish moving with the flow and those moving against the flow were compared with an even distribution of the total number of movements. Only detections recorded in a tributary and then subsequently in coastal habitat, or vice versa, within a $2 \mathrm{~h}$ period were included in this analysis. Detections beyond this $2 \mathrm{~h}$ window were excluded to help 
ensure that the movements occurred during either an ebbing or flooding tide, but not both. Movements to and from the Ashburton River were also excluded because the coastal habitat near the river was largely unmonitored (see 'Results').

Size classes were grouped by their approximate age following Peverell (2009). Neonates consisted of individuals that were recently pupped, as made evident by the presence of an open yolk-sac scar or remnants of a gelatinous sheath on the rostrum. Older young-of-the-year (age ca. 6 to 12 mo, assuming a parturition date of 1 October; see Morgan et al. 2015) were classified as age $0+\mathrm{yr}$. Individuals between 1380 and $1644 \mathrm{~mm}$ TL were classified as age 1+ yr, and those $>1855 \mathrm{~mm}$ TL were classified as age $>1+$ yr. One sawfish (ID 28) at the time of capture had recently had its rostrum illegally severed. To estimate the TL of the amputee sawfish, we used the $P$. zijsron captured during this study (i.e. 38 intact individuals) to determine the relationship between TL and total rostrum length (TRL) as TRL $=0.2544 \times \mathrm{TL}$ +8.164 . Using this equation, sawfish \#28 had an estimated TL of $1949 \mathrm{~mm}$ and a TRL of $504 \mathrm{~mm}$. The movement patterns and fate of this individual were discussed in Morgan et al. (2016).

\section{RESULTS}

A total of 39 individual green sawfish Pristis zijsron were captured during the study (21 females and 18 males), 10 of these in April and 29 in October 2011. Of these, 37 were fitted with acoustic transmitters within the Ashburton River $(\mathrm{n}=29)$, Hooley Creek $(\mathrm{n}=3)$, and Four Mile Creek $(\mathrm{n}=5)$, in April $(\mathrm{n}=10)$ and October $(\mathrm{n}=27)$ (Table 1$)$. The mean catch per unit effort (CPUE) of P. zijsron caught across all sites and sampling events was $72.58 \pm 43.46$ (SE) individuals in $500 \mathrm{~m} \mathrm{net}^{-1} \mathrm{~d}^{-1}$.

TL of captured $P$. zijsron ranged between 767 and $2933 \mathrm{~mm}$ (April: 1122-2447 mm; October: 767$2933 \mathrm{~mm}$, whereby the smallest individual was not fitted with a transmitter but tagged with a rototag) (Table 1). Uncalcified claspers indicated that all of the captured males were sexually immature; females were also possibly sexually immature, but limited information exists regarding size at maturity for this species. Most $P$. zijsron within the smallest cohort (i.e. P. zijsron of 767-972 mm TL) captured in October were considered neonates as they all had open or partly healed yolk-sac wounds, with one possessing the remnants of a yolk sac and rostral sheath.
A total of 287404 detections were recorded by the VR2W receivers in the study area, with between 12 and 41283 detections individual $^{-1}$. P. zijsron were at liberty for between 14 and 525 d (median: 85 d), noting that estimated tag life was 514 d (Table 1, Fig. 2). During these periods, P. zijsron were detected on 1484 d (median: $50 \mathrm{~d}$ ) (note that individuals were deemed present if they were detected more than once in a day, excluding VR4-Global data) (Table 1, Fig. 2). Two tags were prematurely removed from the study area during the study period (i.e. sawfish \#6 was found dead in an illegal gill net and sawfish \#30 had its tag removed by a recreational fisher).

In total, 29, 14, and 9 individually tagged $P$. zijsron were detected in the Ashburton River, Hooley Creek, and Four Mile Creek, respectively. Individuals were detected within the array throughout the entire study, which demonstrates the surveillance capacity of the array (Table 1). Detection of all transmitters ceased for a period in the Ashburton River during a large flow event in January 2012, but most sawfish returned after flows declined a few weeks later, including neonates that were tagged in October 2011 (Figs. 3 \& 4). Similar decreases in detections were observed in Hooley Creek during this period of increased precipitation. Temperature sensors on tagged $P$. zijsron demonstrated individuals occupied water temperatures ranging between $\sim 15$ and $35^{\circ} \mathrm{C}$, with highest temperatures (range: $26-35^{\circ} \mathrm{C}$ ) recorded during late summer and early autumn.

Primary habitat of tagged sawfish (i.e. the site where the greatest number of detections occurred for an individual) included the mouth of the Ashburton River (43.5-100\% of an individual's detections, $\mathrm{n}=28$ ), Hooley Creek mouth (26.4-100\% of an individual's detections, $n=6$ ), and the mouth of Four Mile Creek (83.2-83.7 \% of an individual's detections, $\mathrm{n}=3$ ). The majority (89\%) of tagged P. zijsron were most commonly detected within the site in which they were initially tagged. Interestingly, only 2 of the 13 tagged neonates were observed to have moved $>700 \mathrm{~m}$ upstream from the river mouth, and only for a short period (Fig. 4), with $92.7 \%$ of all detections of neonates being in $<0.5 \mathrm{~m}$ depth. Similarly, only 2 of the 15 older (i.e. age $>6 \mathrm{mo}$ ) juveniles known to have been in the Ashburton River at some stage were recorded by the most upstream receiver (fish ID 5 had 5 detections on one day in February 2012, and fish ID 37 had 962 detections between late November 2011 and 3 January 2012).

$P$. zijsron occupied the study area for between 1 and 344 continuous days (median: $16 \mathrm{~d}$ ) (Table 1, Fig. 5). P. zijsron was absent from the study area for 
Table 1. Sawfish identification number (ID), total length (TL), sex, capture site and date, and residency information of green sawfish Pristis zijsron tagged in the study area. FMC: Four Mile Creek, HC: Hooley Creek, AR: Ashburton River mouth, Cont. days present: greatest period of contiguous days a sawfish was present, and Cont. days absent: greatest period of contiguous days a sawfish was absent

\begin{tabular}{|c|c|c|c|c|c|c|c|c|c|}
\hline ID & $\begin{array}{c}\mathrm{TL} \\
(\mathrm{mm})\end{array}$ & Sex & $\begin{array}{l}\text { Tagging } \\
\text { site }\end{array}$ & $\begin{array}{l}\text { Tagging } \\
\text { date } \\
\text { (d-m-y) }\end{array}$ & $\begin{array}{l}\text { Days at } \\
\text { liberty }\end{array}$ & $\begin{array}{c}\text { Days } \\
\text { present }\end{array}$ & $\begin{array}{c}\text { Cont. } \\
\text { days } \\
\text { present }\end{array}$ & $\begin{array}{l}\text { Cont. } \\
\text { days } \\
\text { absent }\end{array}$ & $\begin{array}{l}\text { Resi- } \\
\text { dency } \\
\text { index }\end{array}$ \\
\hline 1 & 1122 & $\mathrm{~F}$ & FMC & 11-Apr-11 & 525 & 484 & 79 & 3 & 0.92 \\
\hline 2 & 1215 & M & $\mathrm{HC}$ & 17-Apr-11 & 525 & 391 & 130 & 27 & 0.75 \\
\hline 3 & 1242 & M & $\mathrm{HC}$ & 14-Apr-11 & 235 & 227 & 109 & 2 & 0.97 \\
\hline 4 & 1260 & $\mathrm{~F}$ & $\mathrm{HC}$ & 17-Apr-11 & 244 & 213 & 112 & 4 & 0.87 \\
\hline 5 & 1317 & $\mathrm{~F}$ & $\mathrm{AR}$ & 16-Apr-11 & 460 & 293 & 61 & 18 & 0.64 \\
\hline 6 & 1492 & $\mathrm{~F}$ & $\mathrm{AR}$ & 16-Apr-11 & $387^{a}$ & 287 & 44 & 22 & 0.74 \\
\hline 7 & 1644 & $\mathrm{~F}$ & FMC & 11-Apr-11 & 335 & 334 & 334 & 1 & 1.00 \\
\hline 8 & 1855 & $\mathrm{~F}$ & $\mathrm{AR}$ & 16-Apr-11 & 165 & 63 & 9 & 12 & 0.38 \\
\hline 9 & 2284 & $\mathrm{~F}$ & FMC & 11-Apr-11 & 355 & 242 & 46 & 14 & 0.68 \\
\hline 10 & 2447 & M & $\mathrm{AR}$ & 16-Apr-11 & 185 & 87 & 25 & 43 & 0.47 \\
\hline 11 & 844 & $\mathrm{~F}$ & $\mathrm{AR}$ & 22-Oct-11 & 77 & 27 & 8 & 14 & 0.35 \\
\hline 12 & 861 & $\mathrm{~F}$ & $\mathrm{AR}$ & 25-Oct-11 & 53 & 33 & 16 & 7 & 0.62 \\
\hline 13 & 864 & M & $\mathrm{AR}$ & 22-Oct-11 & 142 & 13 & 6 & 124 & 0.09 \\
\hline 14 & 870 & $\mathrm{~F}$ & $\mathrm{AR}$ & 25-Oct-11 & 40 & 4 & 2 & 35 & 0.10 \\
\hline 15 & 878 & M & $\mathrm{AR}$ & 25-Oct-11 & 26 & 23 & 16 & 2 & 0.89 \\
\hline 16 & 887 & $\mathrm{~F}$ & $\mathrm{AR}$ & $26-$ Oct-11 & 58 & 15 & 3 & 14 & 0.26 \\
\hline 17 & 917 & M & $\mathrm{AR}$ & 26-Oct-11 & 141 & 34 & 5 & 45 & 0.24 \\
\hline 18 & 927 & $\mathrm{~F}$ & $\mathrm{AR}$ & 25-Oct-11 & 16 & 14 & 8 & 1 & 0.88 \\
\hline 19 & 930 & $\mathrm{~F}$ & $\mathrm{AR}$ & $26-$ Oct-11 & 136 & 38 & 34 & 66 & 0.28 \\
\hline 20 & 936 & $\mathrm{~F}$ & $\mathrm{AR}$ & $26-$ Oct-11 & 78 & 21 & 6 & 22 & 0.27 \\
\hline 21 & 942 & M & $\mathrm{AR}$ & 22-Oct-11 & 69 & 42 & 13 & 7 & 0.61 \\
\hline 22 & 953 & $\mathrm{~F}$ & $\mathrm{AR}$ & 26-Oct-11 & 14 & 1 & 1 & 13 & 0.07 \\
\hline 23 & 972 & M & $\mathrm{AR}$ & 26-Oct-11 & 68 & 11 & 2 & 35 & 0.16 \\
\hline 24 & 1350 & $\mathrm{~F}$ & $\mathrm{AR}$ & 25-Oct-11 & 200 & 66 & 10 & 32 & 0.33 \\
\hline 25 & 1380 & $\mathrm{~F}$ & $\mathrm{AR}$ & $26-$ Oct-11 & 319 & 239 & 72 & 17 & 0.75 \\
\hline 26 & 1413 & M & FMC & $20-$ Oct-11 & 149 & 148 & 125 & 1 & 0.99 \\
\hline 27 & 1526 & M & $\mathrm{AR}$ & 26-Oct-11 & 494 & 412 & 186 & 17 & 0.83 \\
\hline 28 & $1949^{b}$ & $\mathrm{M}$ & $\mathrm{AR}$ & 27 -Oct-11 & 75 & 28 & 7 & 22 & 0.37 \\
\hline 29 & 1990 & M & $\mathrm{AR}$ & $26-$ Oct-11 & 75 & 48 & 10 & 5 & 0.64 \\
\hline 30 & 2084 & M & FMC & $20-$ Oct-11 & $89^{a}$ & 88 & 73 & 1 & 0.99 \\
\hline 31 & 2170 & $\mathrm{~F}$ & $\mathrm{AR}$ & 22-Oct-11 & 61 & 49 & 26 & 9 & 0.80 \\
\hline 32 & 2226 & M & $\mathrm{AR}$ & 22-Oct-11 & 72 & 48 & 14 & 8 & 0.67 \\
\hline 33 & 2440 & $\mathrm{~F}$ & $\mathrm{AR}$ & 25-Oct-11 & 59 & 52 & 15 & 2 & 0.88 \\
\hline 34 & 2550 & M & $\mathrm{AR}$ & 25-Oct-11 & 80 & 50 & 14 & 8 & 0.63 \\
\hline 35 & 2660 & M & $\mathrm{AR}$ & $22-$ Oct-11 & 75 & 37 & 7 & 11 & 0.49 \\
\hline 36 & 2873 & $\mathrm{~F}$ & $\mathrm{AR}$ & 22-Oct-11 & 85 & 62 & 41 & 5 & 0.73 \\
\hline 37 & 2933 & M & $\mathrm{AR}$ & 26-Oct-11 & 78 & 69 & 41 & 3 & 0.89 \\
\hline
\end{tabular}

between 1 and 124 continuous days (median:12 d; Table 1). The RI of tagged individuals within the study site ranged between 0.07 and 1.0 (Table 1). The RI of neonate $P$. zijsron $(0.37 \pm 0.08)$ was significantly smaller than all other age classes $(\mathrm{p}<0.05)$, including older 0+ P. zijsron; however, they were almost exclusively detected on 1 or 2 receivers adjacent to the site of their initial tagging, i.e. the mouth of the Ashburton River. Excluding the neonates, mean $( \pm \mathrm{SE}) \mathrm{RI}$ decreased with size and was $0.83 \pm 0.06$ for older $0+$ P. zijsron, $0.77 \pm 0.10$ for $1+$ fish, and $0.66 \pm 0.05$ for
$>1+$ fish, although this difference was not significant ( $p>0.05$ ). Only 13 of the 37 tagged P. zijsron were detected in the coastal habitat. However, the actual number of $P$. zijsron found to occur in coastal habitats was likely to be greater than observed, noting the poor receiver coverage outside of the Ashburton River. Residency of $P$. zijsron in coastal habitats ranged between 0.06 and $0.48(0.12 \pm 0.04 \mathrm{SE})$. The mean residency value of $P$. zijsron in the monitored coastal region was significantly lower than those in the sheltered mangrove creeks $(\mathrm{p}<0.001)$. 


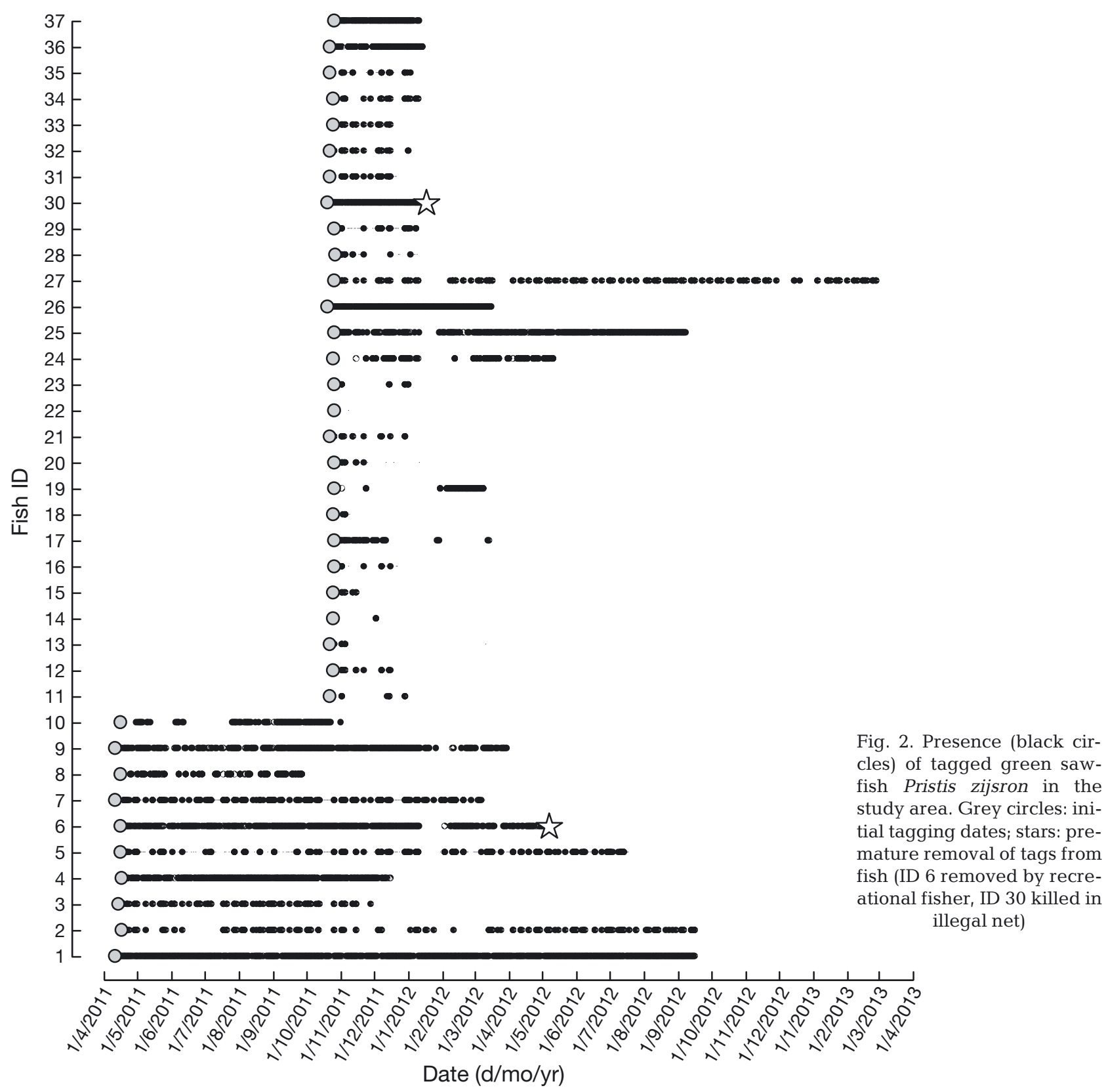

With the exception of neonates, $37.8 \%$ of tagged fish moved between mangrove creeks at least once, with $10.8 \%$ of sawfish moving between creeks on at least 10 occasions (Fig. 6). The standardised total distance (taking into account the distance and frequency of movements) travelled between creeks was observed to have a moderate positive correlation with TL of sawfish (Pearson product-moment correlation, $\mathrm{r}=$ $0.56, \mathrm{p}<0.001$ ) (Figs. $6 \&$ 7). In addition, the percentage of tagged sawfish to move between mangrove creeks also increased with size. Of the sawfish that were tagged in either Hooley Creek or Four Mile Creek, $50 \%$ of the $0+$ (no neonates were observed in these creeks), and all $1+$ and $>1+P$. zijsron were observed to move at least once between neighbouring creeks (a distance of $2 \mathrm{~km}$ ). Movement of P. zijsron between the Ashburton River and Hooley or Four Mile Creek (a distance of 13.5-15.5 km) occurred at least once in 14 and $42 \%$ of $1+$ and $>1+P$. zijsron, respectively, but did not occur in neonates or $0+$ fish.

The number of movements that were observed to occur in the direction of tidal flow was significantly skewed from an equal distribution in Four Mile Creek (chi-squared goodness-of-fit test, df $=1, \mathrm{p}<$ 0.01), but not Hooley Creek (chi-squared goodnessof-fit test, $d f=1, p>0.1$ ). In Four Mile Creek, 93.1\% 


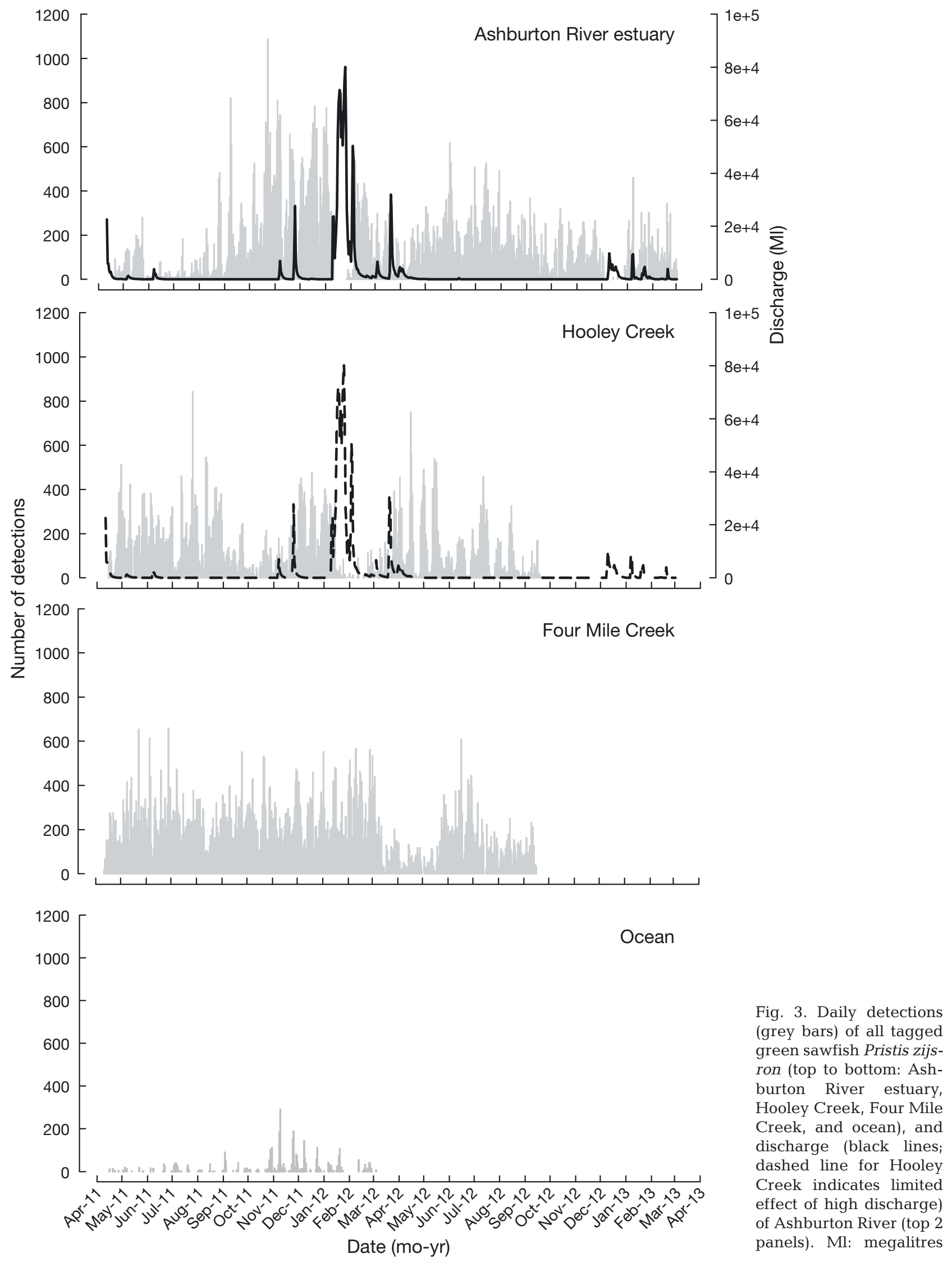




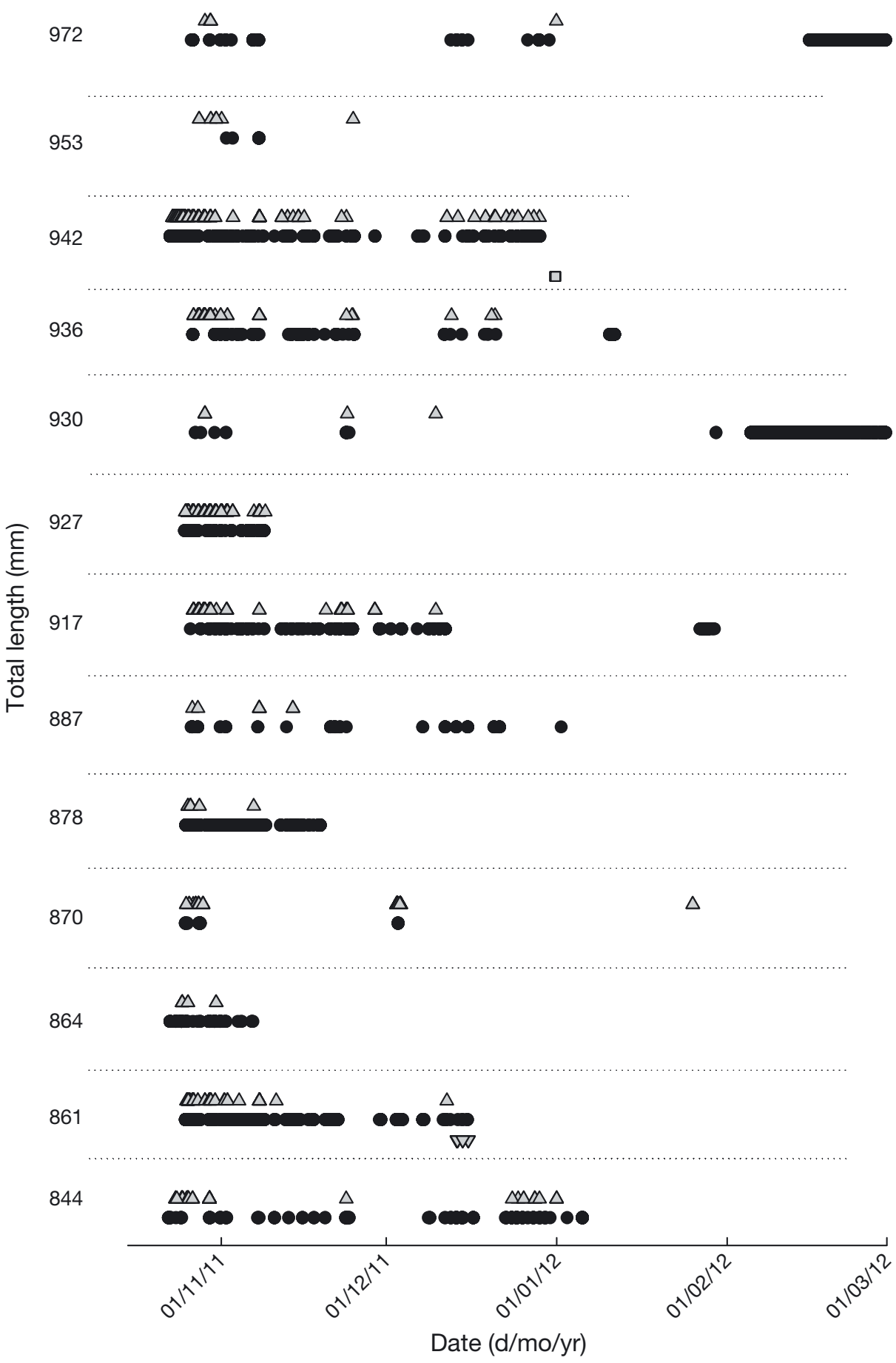

$\triangle 0.3 \mathrm{~km}$ from river mouth

- $0.7 \mathrm{~km}$ from river mouth

$\nabla 1.7 \mathrm{~km}$ from river mouth

$2.8 \mathrm{~km}$ from river mouth
Fig. 4. Presence histories of 13 neonate green sawfish Pristis zijsron tagged in October 2011 in Ashburton River Estuary and movement between 3 VR2W receivers and a VR4-Global receiver
( $\mathrm{n}=145$ ) of the movements to and from the creek were in the direction of tidal flow. In Hooley Creek, $60.6 \%$ ( $\mathrm{n}=99$ ) of the movements to and from the creek were in the direction of tidal flow.

The number of detections recorded by receivers in both the coastal and mangrove creek habitats were significantly different between hours of the day (chi-squared goodness-of-fit test, df $=23$, p < 0.05), when pooling receivers within their respective habitats. Within the mangrove creeks, the number of detections was greater between 18:00 and 08:59 h than between 09:00 and 15:59 h, a trend opposite to that relating to wind speed. The number of detections recorded by coastal receivers was greater between 00:00 and 08:59 $\mathrm{h}$ than between 09:00 and 11:59 h. Wind direction changed between these 


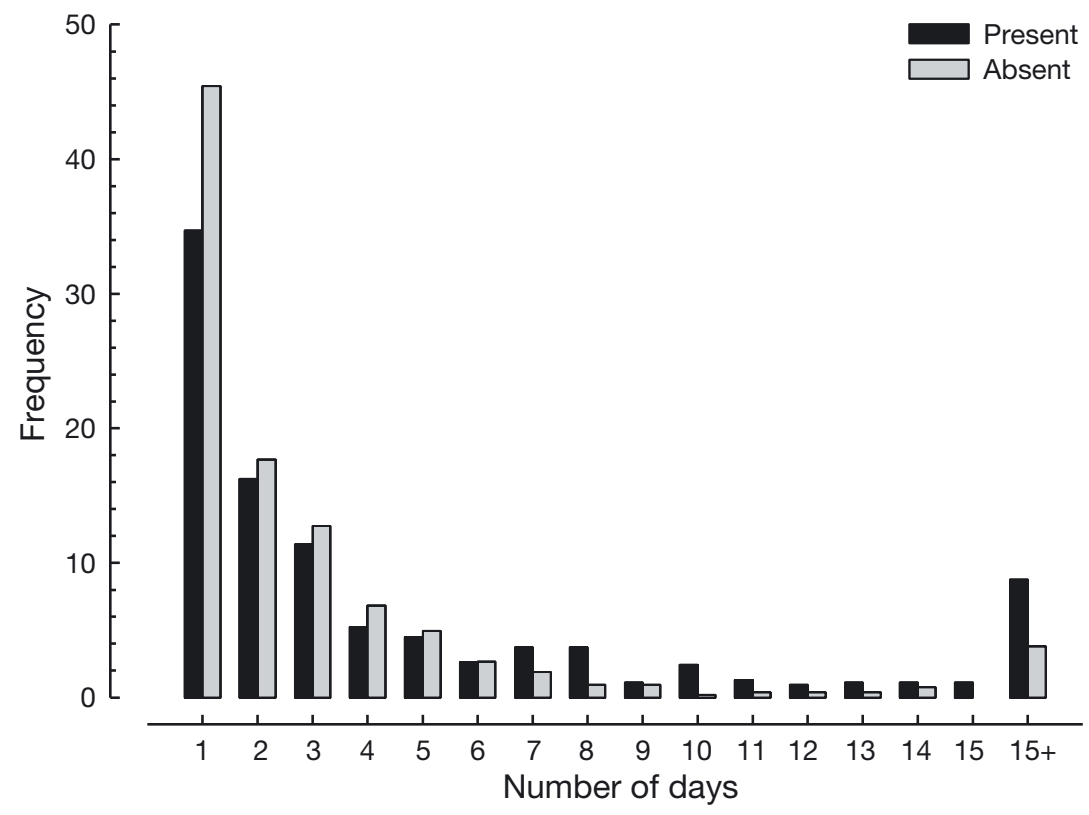

Fig. 5. Number of contiguous days that green sawfish Pristis zijsron were detected within the study area skewed with modes at 150-200 cm tidal height, similar to the distribution of the tidal heights present during the study (see Fig. 10). Conversely, visits to coastal habitats occurred typically at lower tides, with a generally rightskewed distribution and with modes at 100-150 cm (Fig. 9).

The best-fit and most parsimonious GAMM model describing the number of detections in the coastal environment included the fixed effects tide height and wind direction. Outputs from this model suggested that the number of detections in coastal environments were higher during low tides than high tides and also decreased in periods of onshore or cross-shore winds (Fig. 9). The bestfit and most parsimonious GAMM model describing the number of detections in the mangrove creek environment included the fixed effects tide height, wind direction, and wind speed (Table 2). Outputs from this model suggested that the number of detections in mangrove creek environments were higher during high tides than low tides and decreased as wind speed increased. Although the model included wind direction as an influential variable on the number of detections, its influence was small and present only during a relatively small window when winds were parallel to shore (Fig. 10).

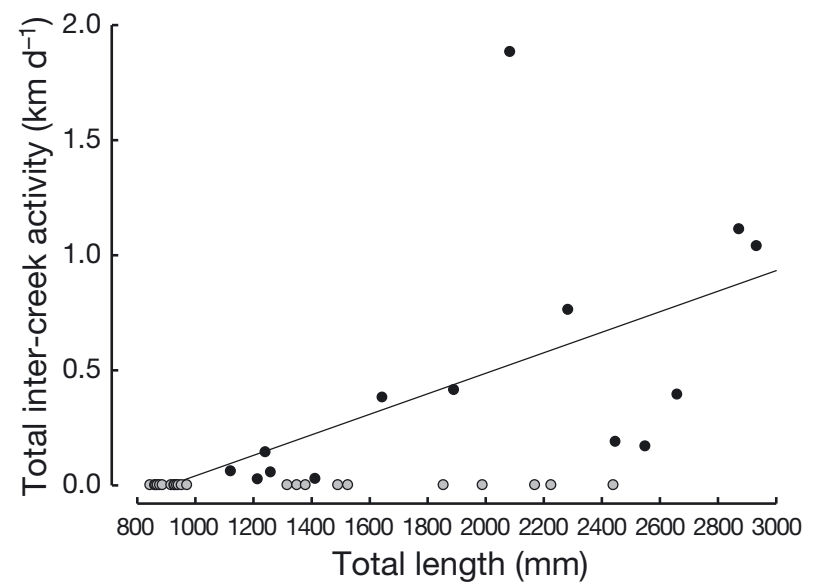

Fig. 6. Inter-creek movements of different sized individual green sawfish Pristis zijsron $(\mathrm{n}=37$ ) during the study. Grey circles: fish that were recorded only in the site where they were initially tagged; black circles: fish that moved between sites

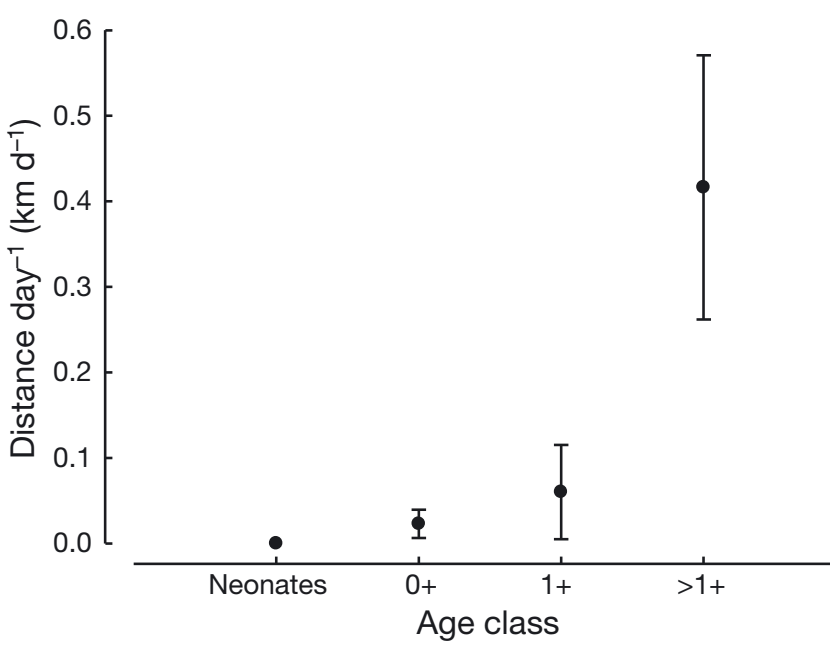

Fig. 7. Distance travelled per day by different age classes (see 'Materials and methods' for definitions) of green sawfish Pristis zijsron during the study. Error bars are SE 


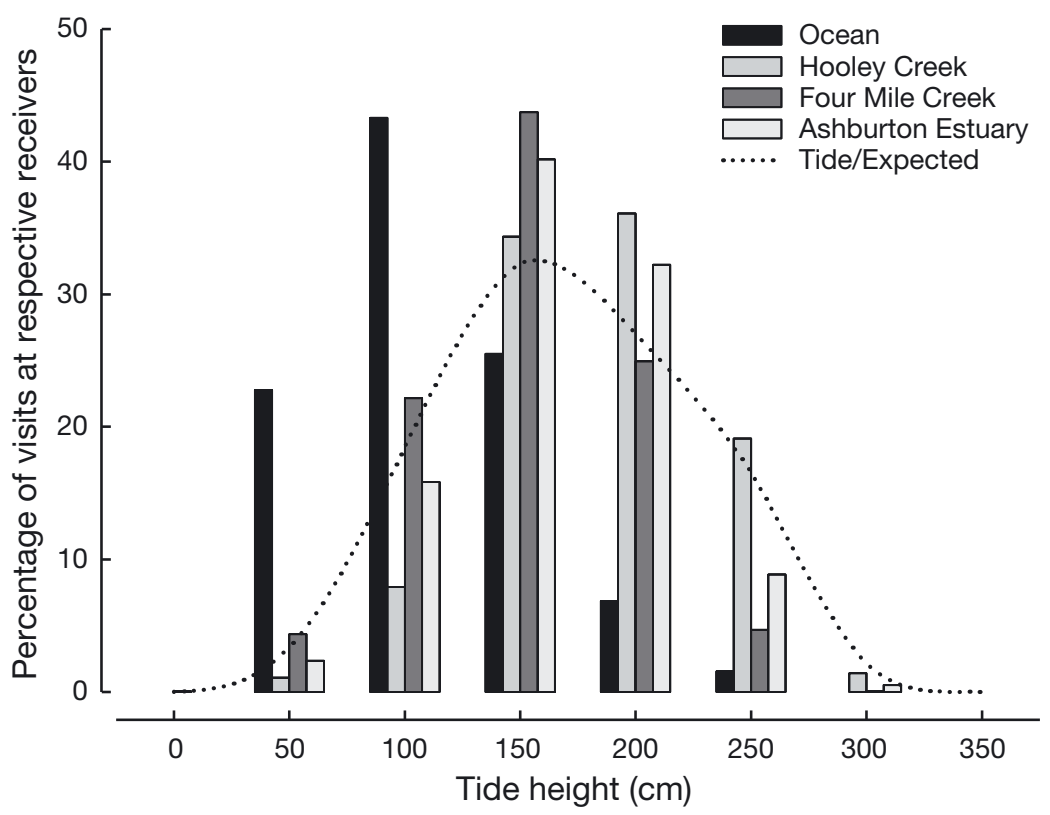

Fig. 8. Comparison of expected and observed presence of green sawfish Pristis zijsron recorded by VR2W acoustic receivers in Hooley Creek, Four Mile Creek, Ashburton River Estuary, and nearshore oceanic waters continuum in use of freshwater, estuarine, and marine use of habitat across sawfish species in the Gulf of Carpentaria (northern Australia), yet CPUE of P. zijsron was orders of magnitude below Pilbara study sites. Peverell (2005) showed that P. zijsron occupy sand and mud flats outside of river mouths, whereas dwarf sawfish $P$. clavata also occupy upper estuarine habitat, and freshwater sawfish $P$. pristis also occupy freshwater. This reinforces the importance of recognising spatial habitat mosaics and complexity within seascape nurseries rather than over-simplifying these nurseries (Nagelkerken et al. 2015).

The current study supports the hypothesis that home-range size increases with growth and development in P. zijsron. Neonates generally stayed close to their initial tagging locations in shallow water $1<0.5 \mathrm{~m}$ depth) for at least their first few

\section{DISCUSSION}

The high abundance and wide range of age classes of green sawfish Pristis zijsron captured and monitored in the vicinity of the Ashburton River delta strongly suggests this to be an important nursery area for the species. However, to determine the significance of this nursery, a more comprehensive understanding of the distribution and habitat use of P. zijsron along the Western Australian coastline and particularly in the Pilbara is required. Based on the current study and current thinking about coastal nurseries for teleosts and elasmobranchs, subsequent surveys for $P$. zijsron should focus on major river mouths and bays, partly to determine hotspots for neonates within larger nursery areas (Morgan et al. 2011, 2015, Poulakis et al. 2011, Nagelkerken et al. 2015). This approach recognises that the population extent of $P$. zijsron is potentially substantial, but that the arrangement of nurseries along the remainder of the sparsely populated Western Australian coast is unknown.

There is a high likelihood that other river mouths and estuaries provide important nurseries for P. zijsron or at least warrant targeted survey effort along the Pilbara coastline, given the findings of the current study and the insight provided by Peverell (2005). The latter study appraised scientific collections and commercial fishery catch records, demonstrating a

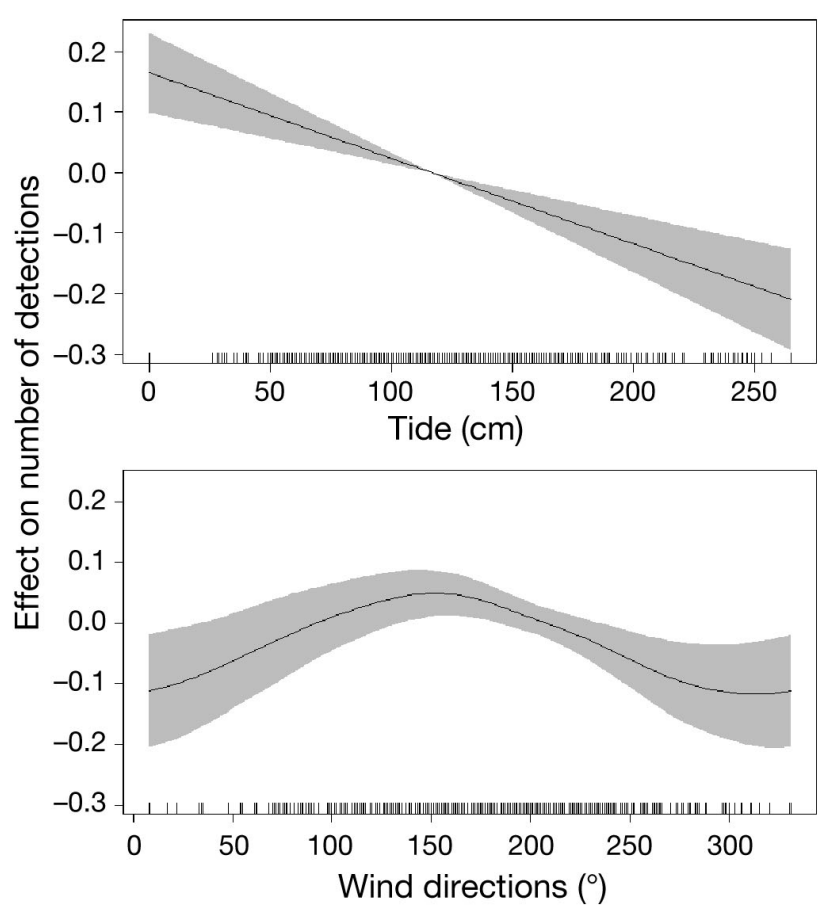

Fig. 9. Influence of tide height (top) and wind direction (bottom) on number of detections of green sawfish Pristis zijsron in nearshore coastal environments. Black line represents the smoothed effect of wind or tide; shaded regions represent $95 \%$ confidence bands. The model suggests that detections were greater during low tides than high tides and decreased in onshore or cross-shore winds 
Table 2. Comparisons of generalised additive mixed effect models constructed to describe the number of transmissions detected by receivers in the tributaries and coastal environments. Individual tags were treated as randomised variables (i.e. random = list $($ Tag $=\sim 1)$ ) in each model. AIC: Akaike's information criterion; bold fonts indicate bestfit and most parsimonious models

\begin{tabular}{|c|c|c|c|}
\hline \multirow[t]{2}{*}{ Model } & \multirow[t]{2}{*}{ df } & \multicolumn{2}{|c|}{ AIC/AIC weight } \\
\hline & & Ocean & Tributary \\
\hline Detections $\sim \mathrm{s}$ (Wind direction) & 4 & $421.5 / 0.00$ & $25166.5 / 0.00$ \\
\hline Detections s(Tide) & 5 & $405.8 / 0.07$ & $25321.9 / 0.00$ \\
\hline Detections s(Wind speed) & 5 & $434.8 / 0.00$ & $24885.7 / 0.00$ \\
\hline Detections $\sim \mathrm{s}($ Tide $)+\mathrm{s}(\text { Wind direction })^{\mathrm{a}}$ & 6 & $400.9 / 0.81$ & $25097.0 / 0.00$ \\
\hline Detections $\sim \mathrm{s}$ (Wind speed)+s(Wind direction) & 6 & $425.5 / 0.00$ & $24688.7 / 0.00$ \\
\hline Detections $\sim \mathrm{s}($ Tide $)+\mathrm{s}$ (Wind speed) & 7 & $409.7 / 0.01$ & $24804.7 / 0.00$ \\
\hline Detections $\sim \mathrm{s}($ Tide $)+\mathrm{s}($ Wind speed $)+\mathrm{s}(\text { Wind direction })^{\mathrm{b}}$ & 8 & $404.9 / 0.11$ & $24623.8 / 0.00$ \\
\hline
\end{tabular}
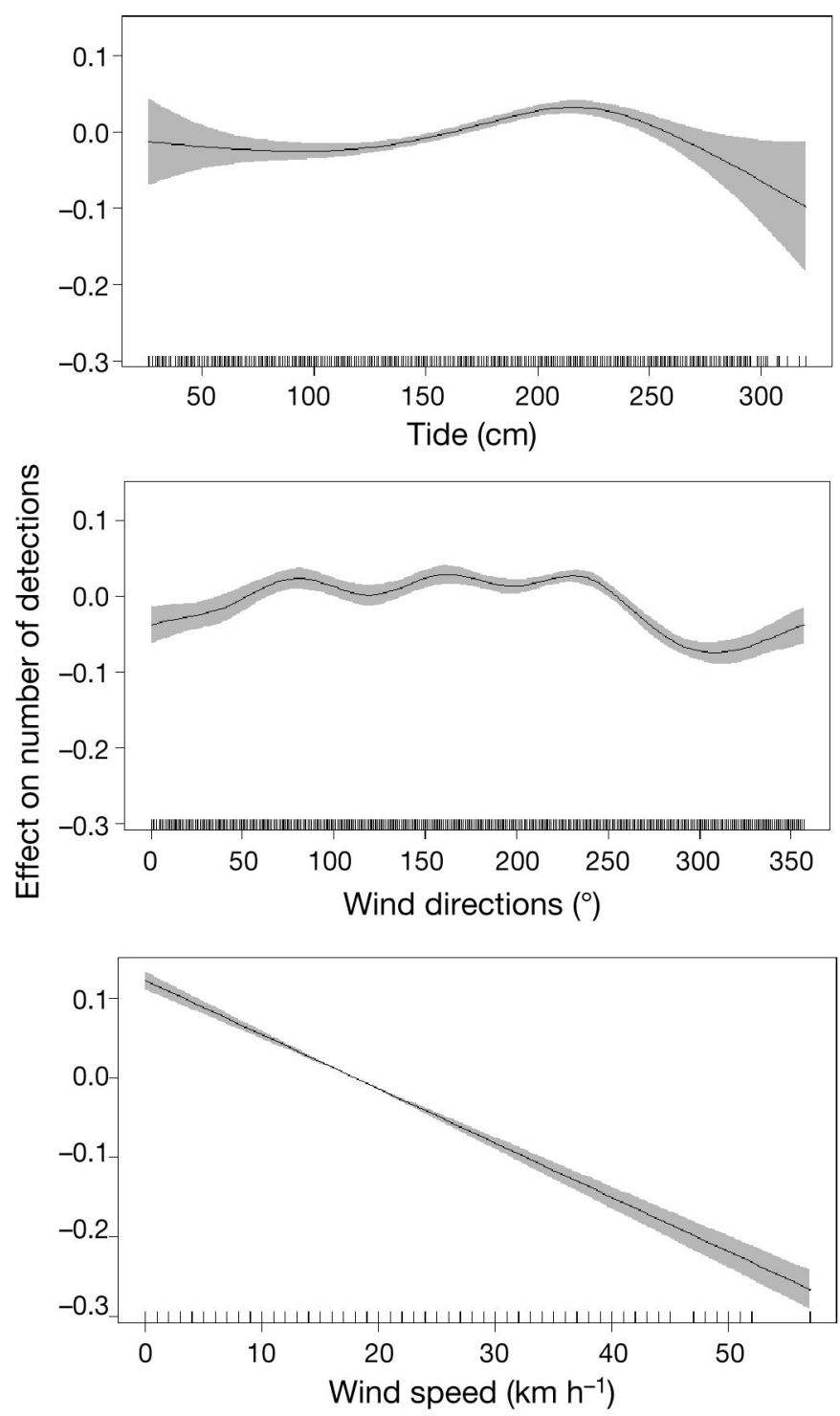

months of life and became increasingly mobile with increasing body size. These findings generally parallel the use of space by juvenile smalltooth sawfish $P$. pectinata as reported from a telemetry study in coastal Florida (Hollensead et al. 2016). However, while tides seemed to have negligible effects on the amount of space used by $P$. pectinata (Hollensead et al. 2016), juvenile $P$. zijsron were more likely to be recorded outside of the estuaries during low tides. The differences between studies may be partly a function of differences between the study systems. For instance, the Everglades National Park site reported in Hollensead et al. (2016) does not experience the discrete, point source flow that occurs at the mouth of the Ashburton River. In addition, the tidal ranges in the Pilbara (generally $>2 \mathrm{~m}$ ) are larger than those in the Everglades (generally $<1.5 \mathrm{~m}$ ). The tide-related movement of P. zijsron in and out of the river mouth has potential ramifications for port management and the planning of major port developments in the Pilbara. At this stage, it is unknown if it is beneficial to protect a subset of river mouths within complex deltas (as is the case with the Ashburton River), or if alternative strategies will result in sustainable sawfish populations or metapopulations in Western Australian waters. At a minimum, in the absence of more information, we recommend that the precautionary approach would be to consider the Ashburton River delta as a high-priority nursery for protecting P. zijsron.

The cessation of detections in the Ashburton River during high freshwater discharge was likely to be a result of the movement of individuals out of the estuary and into nearshore marine waters, suggesting that the low-salinity waters do not provide favourable conditions for the species. However, following

Fig. 10. Influence of tide height (top), wind direction (middle), and wind speed (bottom) on the number of detections of green sawfish Pristis zijsron in the Ashburton River mouth and within Hooley Creek and Four Mile Creek. Black line represents the smoothed effect of tide, wind direction or wind speed; shaded regions represent 95\% confidence bands. The model suggests that detections were greater during high tides and during low wind, and varied depending on wind direction 
flooding, the river and estuary experience high shortterm turbidity; conversely, in the periods between flow events, the waters are characterised by low turbidity (Chevron Australia 2010). Elasmobranchs rely on a number of senses while foraging, from early prey detection, tracking, orientation to, and capture of the prey (Gardiner et al. 2014). Preliminary data suggest that $P$. zijsron possess the least intricate lateral line system (used for mechanoreception of prey, orientation, and predator avoidance) of all 4 Australian sawfishes (Wueringer et al. 2011a). P. zijsron has a much lower number of ampullae of Lorenzini (a close-range sensory system) on both the ventral and dorsal surface of the head compared to P. pristis, which is an electroreception specialist in turbid estuaries and freshwaters (Wueringer et al. 2011b). Thus, the absence of acoustic detections from the Ashburton River estuary and Hooley Creek during flooding periods may have been due to an avoidance of the highly turbid waters, which may have reduced feeding efficiency, and increased predation risk.

Disruption of acoustic transmissions has been reported under high flow conditions (Voegeli et al. 1998, Heupel et al. 2006); however, detections within Hooley Creek, which does not experience high flows like the river, were also observed to decrease during periods of high precipitation. These observations contrast with those in Four Mile Creek, which borders high-saline-retention ponds. Movement away from low-salinity and highly turbid environments contrasts with $P$. pristis, which uses freshwaters whereby neonates migrate upstream during freshwater flows, but is similar to $P$. pectinata, which moves downstream during freshwater flow events (Poulakis et al. 2013). However, P. pectinata moves further upstream than $P$. zijsron, which remained close to the mouth of the river $(<1 \mathrm{~km}$ upstream of the river mouth), suggesting that $P$. zijsron is less tolerant of low-saline conditions than $P$. pristis and $P$. pectinata.

The relatively low RIs of neonates compared to larger juveniles may be a consequence of the receivers failing to detect them when they occupy these extremely shallow habitats. For conspecifics, younger age classes also inhabit shallower water than larger individuals (Whitty et al. 2009, Simpfendorfer et al. 2010). Occupancy of the shallow expanse at the mouth of the Ashburton River, where these fish were initially captured, may have frequently rendered them undetectable. Conversely, Simpfendorfer et al. (2010) found residency of the younger individuals of $P$. pectinata in an estuarine system in Florida, USA, to be far less than was the case for larger individuals. It was hypothesised that this may be due to the limited habitat and prey availability for these individuals, forcing them to move to other areas. Our data support the first argument, as they were generally only recorded at 1 or 2 adjacent receivers, suggesting they had very small home ranges in the river.

The Ashburton River mouth provides important habitat for $P$. zijsron in the southern Pilbara. The majority of tagged individuals (29/37) were recorded in that area, and neonates were present for the first several months of the year, which included their first few months of life. In the absence of comparable data from any other studies, the southern Pilbara currently represents the only known neonate nursery habitat for the species. The importance of the Ashburton River for neonate $P$. zijsron, and the nearby tidal creeks for larger $0+$ and $>0+P$. zijsron, is highlighted in the high CPUE of $P$. zijsron in the study area (see also Morgan et al. 2015). The high CPUE of P. zijsron may be a reflection of the complete absence of commercial fishing (and its deleterious effects on sawfishes) in the river mouths and tidal creeks near the Ashburton River. This is in contrast to a comparably lower CPUE of $P$. zijsron in the presence of commercial fishing in similar habitats in the Gulf of Carpentaria (Peverell 2005). Presumably, net-based fisheries prove destructive to this resident species. Although the juvenile nursery habitats in Western Australia are not currently subjected to commercial fishing, large juveniles and adults that move into deeper waters of the Pilbara are captured in the Pilbara Fish Trawl Fishery (4 tonnes in 2001) (Stephenson \& Chidlow 2003).

The expansive and sparsely populated coastline of central and northern Western Australia provide one of the few global refuges for sawfishes, probably as a result of little human pressure on those populations, both in terms of intact habitat and low fishing pressure. Despite this, it is of concern that in the few short visits in 2011 and 2012 by our research team, we witnessed evidence of trophy-collecting of saws and illegal gill-netting negatively affecting sawfish (Morgan et al. 2016). As the human population is still increasing in northern Western Australia, such incidences may continue and possibly become more prevalent. Therefore, we recommend that management decisions should aim to avoid Western Australian populations of sawfishes suffering the same fate as those of so many other coastlines globally. Indeed, the restricted movement of neonate $P$. zijsron suggests that even small management interventions could have significant benefits in conserving a hotspot for this 
species, whether these are marine protected areas, better enforcement, or simple campaigns educating the public about the conservation status of sawfishes. Western Australia is still in the fortunate situation where proactive steps can be taken to prevent largescale population collapses of $P$. zijsron. Based on the global importance of the region for pristid conservation, it would be prudent to act while populations remain healthy and before human pressure escalates in these once-remote places.

Acknowledgements. We thank the people of Onslow that assisted with the project, particularly Geoff Herbert and Andrew Slater (Scubaroo Dive). Thanks also to Mat Fraser and Travis Hurley (URS Australia) and Glen Young, Tony Rouphael, Ceri Morgan, Steve Moore, Joe Sanderson and Neil Page (Chevron Australia Pty Ltd) for help with logistics. This project was funded by Chevron Australia Pty Ltd and administered through the Western Australian Science Institution. The study adhered to the conditions of the Murdoch University Animal Ethics Committee and the Department of Fisheries, Government of Western Australia. We acknowledge the input of the referees who greatly assisted with structuring of the manuscript.

\section{LITERATURE CITED}

Chevron Australia (2010) Draft environmental impact statement/environmental review and management programme for the proposed Wheatstone Project. Chevron Australia, Perth

Dulvy NK, Fowler SL, Musick JA, Cavanagh RD and others (2014) Extinction risk and conservation of the world's sharks and rays. eLife 3:e00590

* Dulvy NK, Davidson LNK, Kyne PM, Simpfendorfer CA, Harrison LR, Carlson JK, Fordham SV (2016) Ghosts of the coast: global extinction risk and conservation of sawfishes. Aquat Conserv 26:134-153

Everett BI, Cliff G, Dudley SFJ, Wintner SP, van der Elst RP (2015) Do sawfish Pristis spp. represent South Africa's first local extirpation of marine elasmobranchs in the modern era? Afr J Mar Sci 37:275-284

Fernandez-Carvalho J, Imhoff JL, Faria VV, Carlson JK, Burgess GH (2014) Status and the potential for extinction of the largetooth sawfish Pristis pristis in the Atlantic Ocean. Aquat Conserv 24:478-497

* Gardiner JM, Atema J, Hueter RE, Motta PJ (2014) Multisensory integration and behavioral plasticity in sharks from different ecological niches. PLOS ONE 9:e93036

* Heupel MR, Semmens JM, Hobday AJ (2006) Automated acoustic tracking of aquatic animals: scales, design and deployment of listening station arrays. Mar Freshw Res $57: 1-13$

Hollensead LD, Grubbs RD, Carlson JK, Bethea DM (2016) Analysis of fine-scale daily movement patterns of juvenile Pristis pectinata within a nursery habitat. Aquat Conserv 26:492-505

Kyne PM, Carlson J, Smith K (2013) Pristis pristis. The IUCN Red List of Threatened Species 2013: e.T18584848A 18620395
Last PR, Stevens JD (2009) Sharks and rays of Australia, 2nd edn. CSIRO Publishing, Melbourne

“Leeney RH, Poncelet P (2015) Using fishers' ecological knowledge to assess the status and cultural importance of sawfish in Guinea-Bissau. Aquat Conserv 25:411-430

McDavitt M (1996) The cultural and economic importance of sawfishes (family Pristidae). Shark News 8:10-11

Moore ABM (2015) A review of sawfishes (Pristidae) in the Arabian region: diversity, distribution, and functional extinction of large and historically abundant marine vertebrates. Aquat Conserv 25:656-677

Morgan DL, Whitty JM, Phillips NM, Thorburn DC, Chaplin JA, McAuley R (2011) North-western Australia as a hotspot for endangered elasmobranchs, with particular reference to sawfishes and the northern river shark. J R Soc West Aust 94:345-358

* Morgan DL, Allen MG, Ebner BC, Whitty JM, Beatty SJ (2015) Discovery of a pupping site and nursery for critically endangered green sawfish (Pristis zijsron). J Fish Biol 86:1658-1663

*Morgan DL, Wueringer BE, Allen MG, Ebner BC, Whitty JM, Gleiss AC, Beatty SJ (2016) What is the fate of amputee sawfish? Fisheries 41:71-73

Nagelkerken I, Sheaves M, Baker R, Connolly RM (2015) The seascape nursery: a novel spatial approach to identify and manage nurseries for coastal marine fauna. Fish Fish 16:362-371

Peverell SC (2005) Distribution of sawfishes (Pristidae) in the Queensland Gulf of Carpentatria, Australia, with notes on sawfish ecology. Environ Biol Fishes 73:391-402

Peverell SC (2009) Sawfish (Pristidae) of the Gulf of Carpentaria, Queensland Australia. MSc dissertation, James Cook University, Townsville

Poulakis GR, Stevens PW, Timmers AA, Wiley TR, Simpfendorfer CA (2011) Abiotic affinities and spatiotemporal distribution of the endangered smalltooth sawfish, Pristis pectinata, in a south-western Florida nursery. Mar Freshw Res 62:1165-1177

* Poulakis GR, Stevens PW, Timmers AA, Stafford CJ, Simpfendorfer CA (2013) Movements of juvenile endangered smalltooth sawfish, Pristis pectinata, in an estuarine river system: use of non-main-stem river habitats and lagged responses to freshwater inflow-related changes. Environ Biol Fishes 96:763-778

Seitz JC, Poulakis GR (2002) Recent occurrence of sawfishes (Elasmobranchiomorphi: Pristidae) along the southwest coast of Florida (USA). Fla Sci 65:256-266

Seitz JC, Poulakis GR (2006) Anthropogenic effects on the smalltooth sawfish (Pristis pectinata) in the United States. Mar Pollut Bull 52:1533-1540

Sheaves M, Baker R, Nagelkerken I, Connolly RM (2015) True value of estuarine and coastal nurseries for fish: incorporating complexity and dynamics. Estuar Coasts 38:401-414

* Simpfendorfer CA (2000) Predicting population recovery rates for endangered western Atlantic sawfishes using demographic analysis. Environ Biol Fishes 58:371-377

Kimpfendorfer CA, Wiley TR, Yeiser BG (2010) Improving conservation planning for an endangered sawfish using data from acoustic telemetry. Biol Conserv 143: 1460-1469

Stephenson P, Chidlow J (2003) Bycatch in the Pilbara trawl fishery. WA Marine Research Laboratories, Department of Fisheries, Government of Western Australia Report to National Heritage Trust 
Thorburn DC, Morgan DL, Rowland AJ, Gill HS (2007) Freshwater sawfish Pristis microdon Latham, 1794 (Chondrichthyes: Pristidae) in the Kimberley region of Western Australia. Zootaxa 1471:27-41

Thorburn DC, Morgan DL, Rowland AJ, Gill HS, Paling E (2008) Life history notes of the critically endangered dwarf sawfish, Pristis clavata, Garman 1906 from the Kimberley region of Western Australia. Environ Biol Fishes 83: 139-145

Thorson TB (1982) The impact of commercial exploitation on sawfish and shark populations in Lake Nicaragua. Fisheries $7: 2-10$

Voegeli FA, Lacroix GL, Anderson JM (1998) Development of miniature pingers for tracking Atlantic salmon smolts at sea. Hydrobiologia 371:35-46

Whitty JM (2011) Utility of a multi-faceted approach in determining the habitat use of endangered euryhaline elasmobranchs in a remote region of northern Australia.

Editorial responsibility: Gregg Poulakis (Guest Editor), Port Charlotte, Florida, USA
MPhil dissertation, Murdoch University

* Whitty JM, Morgan DL, Peverell SC, Thorburn DC, Beatty SJ (2009) Ontogenetic depth partitioning by juvenile freshwater sawfish (Pristis microdon: Pristidae) in a riverine environment. Mar Freshw Res 60:306-316

Whitty JM, Phillips NM, Thorburn DC, Simpfendorfer CA, Field I, Peverell SC, Morgan DL (2014) Utility of rostra in the identification of Australian sawfishes (Chondrichthyes: Pristidae). Aquat Conserv 24:791-804

Wood SN (2006) Generalized additive models: an introduction with R. Chapman \& Hall, Boca Raton

* Wueringer BE, Peverell SC, Seymour J, Squire L Jr, Collin SP (2011a) Sensory systems in sawfishes. 2. The lateral line. Brain Behav Evol 78:150-161

*Wueringer BE, Peverell SC, Seymour J, Squire L Jr, Kajiura SM, Collin SP (2011b) Sensory systems in sawfishes. 1. The ampullae of Lorenzini. Brain Behav Evol 78:139-149

Submitted: September 2, 2016; Accepted: June 16, 2017 Proofs received from author(s): September 6, 2017 